DOBROCHNA HILDEBRANDT-WYPYCH

Uniwersytet im. Adama Mickiewicza

w Poznaniu

\title{
THEORY AND PRACTICE \\ OF POLITICAL SOCIALIZATION IN CHILDHOOD - DEMOCRACY VS. NEOLIBERALISM
}

ABSTRAct. Hildebrandt-Wypych Dobrochna, Theory and Practice of Political Socialization in Childhood - Democracy vs. Neoliberalism [Teoria i praktyka socjalizacji politycznej w edukacji wczesnoszkolnej - demokracja kontra neoliberalizm]. Studia Edukacyjne nr 45, 2017, Poznań 2017, pp. 255-265. Adam Mickiewicz University Press. ISSN 1233-6688. DOI: 10.14746/se.2017.45.17

The text focuses on the efficiency of school as one of the key agents of political socialization of early childhood students. Using the conceptual framework of J. Astuto and M.D. Ruck, a question is posed of how to effectively develop prosocial skills of children and therefore how to shape their later willingness to engage in civic actions in youth. According to various scholars, prosocial skills, such as respect for others' feelings, helping, sharing and cooperating with others, have to be nurtured through classroom-based play. Unfortunately, in the age of neoliberal dominance of standardized tests, civic education is deemed less important, with an excessive focus on civic knowledge and the insufficient (not testable) focus on civic skills. In reference to research results (e.g. C. Flanagan and L.S. Gallay), the author of the article points out that democratic competence does not simply emerge as a result of top-down transmission of knowledge. The process of normative (moral) development in childhood knowledge of political facts is significantly less important than the child's social experience of civic participation and cooperation. Contrary to the neoliberal tendencies in educational reforms, democracy-learning - as pointed out by numerous studies - should be based on the development of a 'democratic self' (values, patterns of behavior, habits), prior to the development of political knowledge. Knowledge should be treated as a second important element of school political socialization of children. The primary focus should be the school's commitment to the development of children's democratic attitudes.

Key words: political socialization, prosocial skills, democracy learning, early-childhood education, neoliberalism

\section{Introduction \\ - political socialization and neoliberalism}

Political socialization aims at reproducing cultural and ideological conditions into which individuals are born. It can be defined as the natural pro- 
cess of absorption of - as Paul Nesbitt-Larking puts it - "knowledge, emotional reaction, values, and opinions about political matters" that begins in early childhood and is continued in adolescence and early adulthood. ${ }^{1}$ Similarly to other forms of cultural communication, political socialization is a mutual, two-way process. In early childhood an individual functions primarily as a recipient of messages sent by various instances of political socialization. In adolescence and early adulthood a greater willingness to challenge the absorbed political knowledge, attitudes and norms appears. The willingness to contest and disagree is reinforced by both the multiplicity of competing ideological positions and contradictory expectations, formulated by different socialization agents - parents, school or media - towards young people. In that sense political socialization can be considered a bi-directional cultural transfer, where children are not simply "inducted" into the political system though formal education, but they "actively assemble their own internal dialogues with the social world that they live in". ${ }^{2}$

The essence of the adolescent and young adult political socialization lies in the readiness to critically evaluate the dominant cultural and ideological positions. As a result, political socialization turns out to be a space of both continuity and change. Paul Nesbitt-Larking describes this duality as follows:

Political socialization can be described as the transmission of a political culture in a political society that is more or less stable. However, political socialization is also a process through which a political culture can be modified, transformed, or even transgressed. ${ }^{3}$

Similar argument is presented by C. Flanagan and L.S. Gallay, who do not consider blind trust and obedience to the authority as necessary civic skills in a democratic society. In their opinion

a mark of maturity in a democracy is to know when to obey and when to question, criticize, or object to the dictates of authorities. Besides respect for civic authorities, children should also learn how to monitor the performance of their leaders and decide whether their dictates ought to be obeyed. ${ }^{4}$

One of the biggest challenges of civic education today is the pressure of the market on social institutions. It transforms a citizen into a consumer, socialized to make responsible and autonomous market choices. Social rights and

\footnotetext{
${ }^{1}$ P. Nesbitt-Larking, Politics, Society and the Media, Ontario 2007, p. 94.

2 R.D. Hess, J.V. Torney-Purta, The Development of Political Attitudes in Children, London and New York 2017, p. 13.

${ }^{3}$ P. Nesbitt-Larking, Politics, Society, p. 94.

${ }^{4}$ C. Flanagan, L.S. Gallay, Reframing the Meaning of "Political" in Research with Adolescents, Perspectives on Political Science, 1995, 24, 1, p. 37.
} 
responsibilities are limited by the efficiency discourse, embodied in the standardized testing movement or the overemphasis on individualism in the educational choice process. As researchers point out, there is a tendency among adolescents to interpret democracy primarily as a space for the enforcement of individual rights. The early 1970s research on American adolescents already revealed that for the majority of American teenagers the primary task of the government was to protect individual freedom, rather then provide social services. C. Flanagan and L. Gallay also refer to a study conducted in 1974 by Roberta S. Sigel and Marilyn B. Hoskin, who "reported that 48 percent of their high school sample defined democracy solely in terms of individual freedom, and over half had little or no comprehension of the meaning of democracy". ${ }^{5}$ The students' idea of democracy was based on the government's commitment to create conditions to achieve private goals. As pointed out by R. Sigel and M. Hoskin after interviewing 1,000 Pennsylvania high school students, "their main concerns are private rather than public or political" ${ }^{6}$ Moreover, Sigel and Hoskin diagnosed poor civic engagement among interviewed youth, indicating "that almost two out of three young people lack the interest and enthusiasm to become actively in the political world around them". ${ }^{7}$ As highlighted by Sheldon Berman, in spite of young people's knowledge of abstract democratic principles, they are hardly interested in applying these principles in everyday-life decision-making situations. ${ }^{8}$

The incompatibility of the market orientation to the concept of - socially oriented - citizenship is a representation of a wider issue, namely the impact of neoliberalism on the construction of the dominant concept of citizenship. Neoliberal rejection of moral obligations and responsibilities of citizens towards their communities is related to the general neoliberal idea of the radically limited reciprocity between citizens and society. ${ }^{9}$ The willingness to undertake an unrestricted civic action in the name of common good has been replaced by a narrow understanding of social responsibility. The value of a citizen-consumer is based on the primary civic obligations in neoliberalism: entrepreneurship, self expression and personal autonomy. In the broader context of transformation of the welfare state and its subordination to the market rationality, Sanford F. Schram et al. write about the shifting meaning and practice of citizenship as follows:

${ }^{5}$ Ibidem, p. 38.

${ }^{6}$ R.S. Sigel, M.B. Hoskin, The political involvement of adolescents, New Brunswick, NJ: 1981, p. 38, cited after S. Berman, Children's Social Consciousness and the Development of Social Responsibility, Albany 1997, p. 34.

7 Ibidem, p. 171-172, cited after ibidem, p. 35.

8 S. Berman, Children's Social Consciousness, p. 34.

${ }_{9}$ Reshaping Welfare States and Activation Regimes in Europe, p. 107. 
Thus, as the state has been restructured to operate according to market rationalities, citizenship too has shifted toward an economic register of identity and practice. The status of the democratic citizen, positioned as one who must decide and act collectively with others to gain preferred policy outcomes, has been eroded and partly displaced by the individualistic market roles of consumer, worker, and paying customer. ${ }^{10}$

The overemphasis on the economic rights of the citizen-consumer is combined with "an overemphasis on psychological individualism - a socioculturally endorsed reification and privileging of the inner psychological lives of individuals". ${ }^{11}$ The cultural and social shift towards self-expression and self-actualization is associated with the evolution of the role of school. Defined in traditional terms, the school is supposed to support students' intellectual and social development. Currently, this approach gives way to the new orientation: the school's focus on students' personal skills and self-fulfillment. Although the "self" tools (including self-enhancement and self-management skills and practices) can be perceived as useful capabilities for later responsible citizenship and civic engagement, there is also a serious probability of falling into extreme. As Jack Martin and Ann-Marie McLellan, in their book "The Education of Selves. How Psychology Transformed Students", point out:

an inwardly focused, detached selfhood that applies such attributes too narrowly, instrumentally, and individualistically can clearly preclude meaningful collaborative participation and engagement in the complex social and political practices of liberal democracies. $^{12}$

\section{Theoretical background - political socialization in childhood}

Robert Hess and Judith Torney-Purta have been researching the mechanisms of political socialization and political attitudes in children already from the 1970s. The Authors identified four major patterns of acquiring knowledge and skills necessary for the political actions and political understanding. The accumulation model deals with the direct acquisition of information and knowledge or behaviour toward political institutions or persons. In the process of accumulative "policy learning" the data is gathered in a complete detachment from the cognitive development and personality traits of an

${ }^{10}$ S.F. Schram at. al., The third level of US welfare reform: governmentality under neoliberal paternalism, [in:] Governing Through Pedagogy: Re-educating Citizens, Ed. J. Pykett, New York 2012, p. 127.

${ }^{11}$ J. Martin, A.-M. McLellan, The Education of Selves. How Psychology Transformed Students, New York 2013, p. 144.

12 Ibidem, p. 145. 
individual child. At the early stage political socialization can be inconsistent and there is no need for logical connection between information acquired and actual attitudes of children. Information about politics (e.g. constitution, elections, or parliament) is transmitted to children (direct teaching by adults) in a scattered way, and it lacks the broader, holistic perspective - the meaning of political processes in the individual and collective life.

The identification model stresses the child's ability and willingness to imitate the behaviour of some significant other (e.g. parent, teacher). Shaping of political orientations (social roles connected with the political actions and attitudes) in the identification model is relevant for the explanation of children's acqusition of parental patterns of political party preference. However, the transmission of political attitudes in the identification model is inadvertent, based on parental influence as role models and not on indoctrination and attempted persuasion of the parental viewpoint to the child. Everyday interaction in the family shape the political identity of children, and attitudes toward political and civic sphere (objects and actions) are imitated directly from another person, be it a parent, teacher or another adult. ${ }^{13}$

Another model of political socialization by R. Hess i J. Torney is the interpersonal transfer model, based upon the notion of affective feelings and relationships with child's first authority figures from public sphere. For example, a child may see the president's power over the country in the same way he or she sees the father's power in the family. Generalization of relationships with persons in the immediate social environment to the political sphere becomes the first attempt of building political attitudes in childhood/early adolescence. A democratic interpersonal experience may be transferred to broader context of general appreciation of democratic rules and laws in society and political system. Similar mechanisms occur in early childhood education. As indicated by M. Buhl, the freedom of speech, as well as active participation in the decision-making processes in the school environment have a decisive influence on children perception of democratic community, society and politics. ${ }^{14}$ On the other hand though, the interpersonal model can also explain the transmission of antidemocratic attitudes between family/school and society. The xenophobic or racist experience as a child in the family or as a student at school leads to the development of xenophobic or racist relationships or patterns of interaction within the social/political system.

The cognitive-developmental model assumes that the child's conceptions of the political system are modified by his of her existing cognitive structure. ${ }^{15}$

${ }^{13}$ R.D. Hess, J.V. Torney-Purta, The development of political attitudes, p. 21.

${ }^{14}$ M. Buhl, The Role of Family Background in Citizenship Education, [in:] Citizenship Education. Theory - Research - Practice, Eds. A. Sliwka, M. Dietrich, M. Hofer, Münster 2006, p. 74.

${ }^{15}$ A.S. McNamee, Breathing the Same Air: Children, Schools and Politics in the Northern Ireland, Houston 2012, p. 128. 
We can teach some more abstract or complex political ideas only to a child who has reached an appropriate developmental level. R. Hess i J. Torney point out that a young child may be capable of comprehending an institution as complex as Parliament only after he or she is ready to grasp the idea of the work of a single parliamentarian. Therefore, it may not be possible to teach a more complex to a child who has not reached an appropriate developmental level, e.g. the developmental prograssion from concrete to abstract thought. ${ }^{16}$

Political socialization research rarely focuses on assessing young children competencies of dealing with politics. The empirical investigation of such issues as concepts of "good citizenship", the scope of political knowledge or the attitudes towards democracy in early formative years is challenging due to the undeveloped (or underdeveloped) literacy skills of young children. Reference to such abstract concepts as democracy, citizenship or political engagement has to be specified using the specially tailored methodological tools. ${ }^{17}$ As suggested by Jennifer Astuto and Martin D. Ruck, the absence of empirical attention on civic engagement in early childhood is caused by the historical focus on researching youth political knowledge and attitudes, as well as adolescents' sociopolitical orientations. However, considering the growing interest in developmental competences for civic engagement, early childhood ought to be examined more carefully as a crucial foundation for later political socialization. ${ }^{18}$

When analyzing the influence of early socialization for the development of civic identity, school functions as a key agent of political socialization. School is usually the first place where democratic values are explicitly introduced to the students. It is also the setting, where key competencies for later civic engagement are developed. A key question is, whether the early childhood development of political orientations in the school context not only aims at the continuity of the current political system and the existing social relations, but also provides tools for the future political and social change in youth and adulthood.

16 R.D. Hess, J.V. Torney-Purta, The Development of Political Attitudes, p. 22.

17 An interesting solution to the metodological challenges in research on political socialization in early childhood appeared in the German research project "Learning to live democracy" (Demokratie leben lernen). Following qualitative interviews with children, teachers and psychologists, a standardized questionnaire was developed. The questionnaire was pictographic and it covered "about 100 items dealing with political knowledge, images of 'good citizenship", desirable social behavior, conceptions of demoracy, political communication, gender roles and attitudes toward political issues and authorities" (L. Wessa, Political Knowledge and Democratic Values. An Empirical Investigation of Political Socialization among Young Children, APSA 2012, Annual Meeting Paper, p. 6-7).

18 J. Astuto, M.D. Ruck, Early Childhood as a Foundation for Civic Engagement, [in:] Handbook of research on civic engagement in youth, Eds. L. Sherrod, J. Torney-Purta, C. Flanagan, New York 2010, p. 249-250. 
Jennifer Astuto and Martin D. Ruck introduced a theoretical model of competencies and skills that can boost the later civic engagement in youth. They identify three crucial competencies of executive function - inhibition, working memory and cognitive flexibility - that enhance future civic engagement and contribute to the development of adolescent civic identity. These cognitive skills - as defined by L. Wray-Lake and A.K. Syvertsen - relate to "the ability to forgo desires in favor or higher-order goals" (inhibition), "the capacity for abstract thinking, necessary for conceptualizing values" (working memory) and "the ability to alter one's perspective and adopt to changing environmental demands" (cognitive flexibility). ${ }^{19}$ All three take part in the process of enhancing prosocial skills. Prosocial skills of children are key elements in the J. Astuto and M.D. Ruck's conceptual framework, mainly because of their decisive impact on the later willingness to engage in civic actions in youth. The Authors highlight that creating opportunities for children to engage in prosocial actions "theoretically support later behaviors and skills needed by youth to become productive members of society (e.g., complex language and reasoning skills, affective regulations skills, and perspective-taking abilities)" ${ }^{20}$ Prosocial skills, such as respect for others feelings, sharing, helping and cooperation with others, have to be nurtured through the classroom-based play. Early childhood classroom functions in children's minds as "the first template of society". From the teacher's perspective early childhood classroom should be a space where children's

engagement in complex imaginative play is linked to the development of the executive-function skill, which includes different elements such as controlling emotions, resisting impulses, and exerting self-control and discipline. ${ }^{21}$

\section{Testing vs. the child's right to play - impediments to civic learning}

Observers of the current educational reforms in both Europe and USA notice a clear shift towards the development of measures to ensure educational accountability, including an intensifying bureaucratic control of classroom teaching and student performance based on standardized testing. The most common complaint that arises in the context of the impact of performance accountability on school curriculum concerns the resignation from

${ }^{19}$ L. Wray-Lake, A.K. Syvertsen, The Developmental Roots of Social Responsibility in Childhood and Adolescence, [in:] Youth Civic Development: Work at the Cutting Edge, Eds. C.A. Flanagan, B.D. Christians, Will Periodicals 2011.

${ }^{20}$ J. Astuto, M.D. Ruck, Early Childhood, p. 256.

${ }^{21}$ Ibidem, p. 257. 
general learning for students' test preparations. Kathryn McDermott, in her analysis of the consequences of performance accountability on schools states that focusing on the tested content "has crowded out the subjects that are not included in states' accountability determinations, such as social studies, physical education, ant the arts". ${ }^{22}$ Such neoliberal educational reforms as the 2002 No Child Left Behind Act (NCLB) affected educational practices and institutions, including childhood classroom practice. As stressed by J. Astuto and M.D. Ruck, as a result of philosophical change in the expectations for young children, greater emphasis was put on didactic skills in early childhood classroom. At the same time less attention was paid to quality play, which was losing in competition with academic activities: reading and mathematics. Unstructured and free play was seen as an unnecessary activity, especially in the light of dominance of skill development over children's social-emotional competencies. ${ }^{23}$

Researchers highlight that too much emphasis put on standardized testing may result in the negligence of civic education. ${ }^{24} \mathrm{~A}$ strong point was made by Meira Levinson in her book entitled "No Citizen Left Behind", where she analyzed the results of standardized testing on civic education. In her opinion standardized testing is an inappropriate measure to promote civic education practice. Responsible and critical civic engagement is not a short-term and easy measurable goal; it is a long-term activity of implementing the ideal of "a more equal society in which today's often disempowered youth become tomorrow's critically engaged, efficacious, and empowered adults". ${ }^{25}$ Because of the practical impossibility to assess civic engagement and civic knowledge based on standardized tests, civic education is not valued very highly. The all-encompassing mania of testing all areas of student school performance there are political expectations of civic education to be subject to high-stakes testing procedure as well. However, researcher point to the limited reliability and ethical controversies of testing civic values, attitudes, and behavior. ${ }^{26}$

In the context of the increasing role of accountability and testing there is a growing opposition between the (excessive) focus on civic knowledge and the (insufficient) focus on civic skills. As indicated by the German Authors of the research on political socialization of young children (Demokratie leben lernen - Learning to live democracy), "political knowledge does not play an im-

${ }^{22}$ K.A. McDermott, High-Stakes Reform: The Politics of Educational Accountability, Washington, DC: 2011, p. 171.

${ }^{23}$ J. Astuto, M.D. Ruck, Early Childhood, p. 264.

${ }^{24}$ See: K.F. Ryan, Lost in the Cave: Citizenship and the Decline of Public Education, Vermont Bar Journal, 2004, 29.

${ }^{25}$ M. Levinson, No Citizen Left Behind, Harvard 2012, p. 259.

${ }^{26}$ P. Levine, The Future of Democracy: Developing the Next Generation of American Citizens, Medford, MA: 2007, p. 153. 
portant role for the development of democratic values orientations - at least not at this early stage of the political socialization process" ${ }^{27}$ As reported by other researchers, political knowledge visibly increases support for democratic values and conventional or unconventional political participation among adults. For example, politically knowledgeable citizens tend to participate in elections more eagerly then their less informed colleagues. ${ }^{28}$ However, positive relationship of political knowledge and democratic conduct is not that visible among young children. The lack of strong relationship between pupils' political knowledge and support for norms of democratic citizenship - as Lisa Wessa point out - may appear at a later stage, with the gradual development of cognitive skills. It is also plausible that in the process of normative (moral) development in childhood knowledge of political facts is significantly less important then a child's social experience of civic participation and cooperation. As indicated in the German study Demokratie leben lernen, transmission of knowledge about political life to children should be complemented by opportunity for children to make their own mind up about the meaning of politics and democratic values. Children's role-playing or group project work are expected to provide valuable input for their understanding of civic rights and responsibilities. It may be possible that "those direct experiences are much more likely to promote considerations about abstract principles of democratic communities than political knowledge".${ }^{29}$ The similar consideration was expressed by Constance Flanagan and Leslie S. Gallay, who pointed out that democratic competence does not simply emerge as a result of top-down transmission of knowledge, beliefs and attitudes, the consequence of a simple acceptance of persuasion of political leaders. "Rather, democratic skills such as engaging in debate, listening to different perspectives on issues, negotiating a compromise, or arriving at consensus develop with opportunity and practice". ${ }^{30}$

\section{Conclusions}

According to Gerhard Himmelmann's understanding of democracy, we can learn about democracy as a social system, democracy as a form of government and - finally - about democracy as a way of life. In this last context learning about democracy can be seen as a Lebenshilfe - a set of experiences

${ }^{27}$ L. Wessa, Political Knowledge and Democratic Values.

${ }^{28} \mathrm{H}$. Milner, The Internet Generation. Engaged Citizens or Political Dropouts, Lebanon NH 2010, p. 98-99.

${ }^{29}$ L. Wessa, Political Konwledge and Democratic Values.

${ }^{30}$ C. Flanagan, L.S. Gallay, Reframing the Meaning of "Political”, p. 36. 
enabling social learning. One of the crucial aspects of democracy-learning is "the development of a 'democratic self' in behaviour, commitments, values and habits", mentioned by G. Himmelmann as first, before another important factor of democracy-learning - the development of political knowledge. ${ }^{31}$ Especially in case of younger children, knowledge should be treated as the second-important element of school socialization to be a good citizen; primary meaning lies in the school's commitment to the development of the democratic attitudes.

Transmission of political knowledge is an indispensable aspect of political socialization. However, it ought to be supplemented with - prior to the transfer of information - the children's experience in the democratic decision-making process in the early childhood classroom. Imaginary play offers a change to develop prosocial behaviours and learn democratic principles in an independent, bottom-up way. This consideration seems to be particularly important in the face of repeated allegations about the excessive individualism, self-absorption and deficit of critical thinking about politics among representatives of younger generations.

\section{BIBLIOGRAPHY}

Astuto J., Ruck M.D., Early Childhood as a Foundation for Civic Engagement, [in:] Handbook of research on civic engagement in youth, Eds. L. Sherrod, J. Torney-Purta, C. Flanagan, John Wiley \& Sons, Hoboken, New York 2010.

Berman S., Children's Social Consciousness and the Development of Social Responsibility, State University of New York Press, Albany 1997.

Buhl M., The Role of Family Background in Citizenship Education [in:] Citizenship Education. Theory - Research - Practice, Eds. A. Sliwka, M. Dietrich, M. Hofer, Waxmann Verlag, Münster 2006

Flanagan C., Gallay L.S., Reframing the Meaning of "Political" in Research with Adolescents, Perspectives on Political Science, 1995, 24, 1.

Hess R.D., Torney-Purta J.V., The development of political attitudes in children, Transaction Publishers, New Jersey 2009; The Development of Political Attitudes in Children, London and New York 2017.

Himmelmann G., Concept and Issues in Citizenship Education. A Comparative Study of Germany, Britain and the USA [in:] Education for Intercultural Citizenship: Concepts and Comparisons, Eds. G. Alred, M. Byram, M. Fleming, [in:] Education for Intercultural Citizenship, Multilingual Matters 2006.

Levine P., The Future of Democracy: Developing the Next Generation of American Citizens, Tufts University Press, Medford, MA: 2007.

Levinson M., No Citizen Left Behind, Harvard University Press, Harvard 2012.

${ }^{31}$ G. Himmelmann, Concept and Issues in Citizenship Education. A Comparative Study of Germany, Britain and the USA in: Education for Intercultural Citizenship: Concepts and Comparisons, Eds. G. Alred, M. Byram, M. Fleming, [in:] Education for Intercultural Citizenship, Multilingual Matters 2006, p. 81. 
Martin J., McLellan A.-M., The Education of Selves. How Psychology Transformed Students, Oxford University Press, New York 2013.

McDermott K.A., High-Stakes Reform: The Politics of Educational Accountability, Georgetown University Press, Washington, DC: 2011.

McNamee A.S., Breathing the Same Air: Children, Schools and Politics in the Northern Ireland, Strategic Book Publishing and Rights Co., Houston 2012.

Milner H., The Internet Generation. Engaged Citizens or Political Dropouts, Tufts University Press, Lebanon NH 2010.

Nesbitt-Larking P., Politics, Society and the Media, Broadview Press, Ontario 2007.

Ryan K.F., Lost in the Cave: Citizenship and the Decline of Public Education, Vermont Bar Journal, 2004, 29.

Schram S.F., Soss J., Houser L., Fording R.C., The third level of US welfare reform: governmentality under neoliberal paternalism, [in:] Governing Through Pedagogy: Re-educating Citizens, Ed. J. Pykett, Routledge, New York 2012.

Sigel R.S., Hoskin M.B., The political involvement of adolescents, Rutgers University Press, New Brunswick, NJ: 1981.

Wessa L., Political Konwledge and Democratic Values. An Empirical Investigation of Political Socialization among Young Children, APSA 2012 Annual Meeting Paper (http://papers.ssrn.com/sol3/JELJOUR_Results.cfm?form_name=journalBrowse\&journal_ id=999063)

Wray-Lake L., Syvertsen A.K., The Developmental Roots of Social Responsibility in Childhood and Adolescence, [in:] Youth Civic Development: Work at the Cutting Edge, Eds. C.A. Flanagan, B.D. Christians, Will Periodicals 2011. 